\title{
Family Reunification: The Case of the Muslim Migrant Children in Europe
}

\author{
By Rita Duca*
}

\begin{abstract}
Adopting a child is not a legal concept recognized in Islamic law, which, while giving great importance to orphans and children's rights, has introduced the legal institution of the Kafala. This institution can be defined as a commitment by the kafil to ensure maintenance, education and protection of a minor makfoul until his legal majority, in the same way as would a father to his son, but without creating any family relationship. For these reasons the Kafala cannot be compared to an international adoption. On one side the Kafala is a legal concept recognized by International Law, in particular by the United Nations Convention of 20 November 1989 on the Rights of the Child, which recognizes the Muslim institution of the Kafala in the article 20 as a means of protection of the children. The aim of this paper is to understand how, in a society increasingly multicultural, the Kafala could be reconciled in Europe, in particular analyzing the EU directive 2003/86/EC of 22 September 2003 on the right to family reunification, which ignored this Muslim institution. In the second part, the paper will analyze the most important judgments in the Italian, French and English legal systems in order to highlight how in these three European countries the solutions adopted in relation to the Kafala have been completely different.
\end{abstract}

\section{Introduction}

The progressive increase of immigrants in Europe has had important effects on the structure and on the functioning of the European Countries' legal systems and will probably requires, in medium term, a change of these systems.

"Family is a fundamental social group, it is in every socially recognized society, which structure and functions change in the course of time and from a society to another"1, and this is why the right of family is the most vulnerable field to cultural-ethnic effects, for (...) both anthropo-sociological and legal reasons".

\footnotetext{
*Post-doctoral Research in Law, University of Palermo, Italy.

${ }^{1}$ BAARSMA, N.A. (2011). The Europeanisation of International Family Law, The Hague, Asser Press, 121.
} 
Indeed, "family" is a polysemous concept, that is, it combines different meanings depending on the actors who turn to it and on the contexts in which it is used, and for this reason, even the experts in civil law don't refer to "family", but to "families".

It is clear how, in a multicultural society, a social model of uniform family does not exist, because when culture, religion and traditions change, "families" will change as well and, as a consequence, familiar relationships between manwoman and parents-children, the educational and existential choices related to children of under age, the idea of marriage or of filiation, the conditions of dissolution of family unit, etc.

This kind of social transformation requires "a rethink of the entire Family law"1 in Western legal systems.

These systems have to take into account not only new familial structures composed by immigrants, but also have to give attention to the identification and custody petitions required by these new families.

In this new background the legal institution of Islamic law of kafala will be analyzed in the Italian, French and English legal systems.

The first problem that arises from kafala within European legal systems is in relation to the right of family reunification.

For this reason, the aim of this paper is to understand how the kafala could be reconciled in Europe, in particular analyzing the EU 2003/86/EC of 22 September 2003 on the right to family reunification, that ignored this Muslim institution.

In other words, it is important to understand if a minor subject sub-kafala has the right to reunite with the family who took him/her into custody and lives regularly in Europe, considering that the above mentioned European directive and the immigration law of the three European Countries (Italy, England and France) don't make any reference to this institution, because they ignore it.

\section{What is Kafala?}

In almost every Islamic Country ${ }^{2}$ adoption of children is prohibited by law that comes directly from the Koran ${ }^{3}$.

The reason of this prohibition is due to the Islamic idea of family as an institution of holy origins in which filial bonds are expressions of Allah's will ${ }^{4}$.

\footnotetext{
${ }^{1}$ MiRANDA, A. (2000). La privatizzazione del diritto di famiglia: il modello di Common Law, in A. Dagnino (cur.) Alambicco del Comparatista II: Matrimonio, Matrimonii, Giuffrè, p. 370.

${ }^{2}$ With the exception of Tunisia, Iraq, Turkey, Somalia and Indonesia. To examine more in depth see AlUFFI BECK-PECCOZ, R. (1997) Le leggi del diritto di famiglia negli Stati arabi del Nord-Africa, Fondazione Giovanni Agnelli, Torino. In particular, Tunisia has introduced child adoption with similar characteristics to adoption in Eurocentric Countries (1958).

3“'Allah hasn't placed for any man two hearts in his body (...) and he did not make your adoptive sons as your own sons". Koran, Sura XXXIII, vers. 4.

4 "Only Allah tells the truth and guides you the right path" Ibidem.
} 
For this reason, man cannot, through artificial juridical bonds, decide on the suspension or the foundation of new filial bounds beyond the biological generation within marriage ${ }^{1}$.

From this we can deduce that, since adoption is an institution whose aim is the making of a filial relationship created independently from natural procreation, it must be prohibited.

The prohibition of adoption established by Allah's law, which in Islamic legal systems has the same relevance as a source of right ${ }^{2}$, is also confirmed in the national legislation of different Islamic Countries ${ }^{3}$.

The lack of instruments useful to create an "unnatural" filial system does not mean, on the other hand, that minor orphans or abandoned children are left in their own destiny.

The duty of brotherhood and solidarity towards abandoned minors, also exhorted by the Koran, is performed by every good Muslim through kafala ${ }^{4}$, which is the only institution recognized by the Islamic law aimed at the guardianship and protection of abandoned childhood.

From these considerations it emerges that this institution is strongly tied, in general, to the traditional social values that defend the Islamic society and, in practice, to its religious values.

Although the discipline of this institution has specific connotations in every single Islamic system, it is possible to identify the essential and common features of this particular form of protection of abandoned children.

Through kafala, a Muslim married couple (or an adult) obtains the custody of a child who was not given to the custody of his/her biological relatives ${ }^{5}$.

In particular, kafil (a couple or an adult ${ }^{6}$ ), through a contract signed before a judge or a notary, commits him/herself to provide, in a definitive way, to the

\footnotetext{
${ }^{1}$ The origin of the Islamic prohibition of adoption is uncertain. According to part of the doctrine it must be considered under historical prospective: see LONG, J. (2005). Il ricongiungimento familiare del minore affidato con Kafala, Diritto di famiglia, 1835-1836.

See also PALERMO, P. (2010). Ricongiungimenti familiari solo per gli stranieri e non per i cittadini: il caso della kafalah, Diritto e Giustizia, 120.

${ }^{2}$ DAVID, René, BrIerley, John E. C. (1985). Major Legal Systems in the World Today: An Introduction to the Comparative Study of Law. London. STEVEnS, "the Muslim law does not represent $[. .$.$] an autonomous branch of Science. It is none other than one Islamic religious$ face".

${ }^{3}$ For example: the 19 June 1984 Algerian law, art. 46 expresses that "l'adoption est interdite par la Chari'a et la loi"; the Libyan law n. 15 from 1984; the "dahir" from Morocco, 18 December 1957, art. 83, claims that "adoption does not have any juridical validity and it does not produce any of the effects of filiation". Similarly, in Syria adoption is not recognized since it is in conflict with the Islamic Shari'a and therefore with Syria's Constitution.

${ }^{4}$ The etymological meaning of the word, translated from Arab, is "to add something to something else".

${ }^{5}$ Kafala does not refer only to the abandoned child, but also to the minor towards which custody in an extended family is not possible. On this issue see A. GALOPPINI, L'adozione del piccolo marocchino, op. cit., p. 143.

${ }^{6}$ For example the Algerian law considers the possibility both couples and singles, whether they are men or women, may become kafil. On the contrary, the Moroccan law restricts this possibility only to couples with at least three years of marriage.
} 
needs of a makful ${ }^{1}$ (abandoned child) until he/she comes of age ${ }^{2}$ and to take care of him/her in the same way as a "good father" would do.

Although kafil has parental responsibility over the child, there is no kind of filiation with the minor ${ }^{3}:$ makful does not take his/her kafil's surname, does not obtain any inheritance rights ${ }^{5}$, nor does he/she interrupt the relationship with his/her family's origins.

From the procedural point of view it is necessary at first to make sure of the makful's condition and kafil's suitability.

Islamic law usually implies that the child is previously considered "abandoned" from the competent juvenile Court, and when biological parents are known, they are summoned to give their approval to kafala.

Moreover, in different Islamic Countries ${ }^{6}$, it is necessary to listen to makful's opinion and obtain his/her approval to kafala.

Islamic law also requires some conditions that need to be satisfied to take care of the abandoned minor. Kafil must: be of age, believe in Islamic religion $^{7}$, be able to guarantee to the child's adequate care and a good growth, and finally fulfill with dignity the parental role $^{8}$ and responsibilities deriving from kafala? .

Competent authorities ${ }^{10}$, in addition to verifying makful ${ }^{\star}$ s condition of abandonment and kafil's suitability, have to verify the compatibility between the two subjects. Once kafala is allowed, the public competent authority keeps the right and the duty of surveillance and checks the evolution of the child's integration in the extended family and in the event of kafil's transfer of residence abroad it must authorize makful's transfer.

As one can deduce by what has been said kafala is and must be considered as a form of protection of abandoned children provided for by legal orders based on the Islamic law. For this reason kafala is, in International law, a valid

\footnotetext{
${ }^{1}$ A peculiarity of this institution is that kafil's commitment is definitive. On this issue see YOUNSI HADDAD, N. (1997). La kafala en droit algérien, in L'enfant et les familles nourricères en droit comparé, Presse de l'Univerisitè des sciences sociales de Toulouse, 135.

${ }^{2}$ In Moroccan law, kafala does not cease at the coming of age but when she gets married.

${ }^{3}$ See CAMPIGLIO C. (2008), Il diritto islamico nella prassi italiana, in Rivista Diritto Interno, 1, 46, "Kafala does not interrupt the juridical bond with the family of origin and it does not have any personal effects on the child".

${ }^{4}$ With particular reference to the impossibility of transmitting the foster parent's name to the foster child see Sura XXXIII, verse 5, "to the adoptive children you have to give their father's surname: this is right in front of God! If you will ignore the fatherhood, may they be brothers in religion; they are with us".

${ }^{5}$ Under the successor profile is, however, considered the possibility that kafil, through the declaration inserted in one's own will (tanzil), the child is equalized to one of is/her heirs.

${ }^{6}$ This is disposed, for ex., from the art. 117 the Algerian Civil law.

${ }^{7}$ In particular, a prerequisite of the kafil's belonging to Islam must be framed in the effort to offer to the child the best family that also guarantees a good education. This prerequisite of the Islamic faith is, clearly in conflict with the principle of laity, accepted from the Western law.

${ }^{8}$ Regarding parental roles, women have to take care of children's growth (hadana), on the contrary, men have the duty of feeding (nafaqa), also the custody, care and parental authority.

${ }^{9}$ These are kafil's general prerequisites. In Algeria, for example, kafil must have Algerian citizenship.

${ }^{10}$ In general it is a specialized judge regarding juvenile Institute at the civil courthouse.
} 
alternative to the forms of protection of children provided for by western rules, in particular as regards to adoption and custody.

In particular, the 1989 United Nations Convention on the Rights of the Child considers among the instruments of protection for children who are permanently or temporarily deprived of their family environment "family custody, kafalah of Islamic law, adoption or, in case of need, the placement in apposite institutions for children", specifying that "making a selection among these solutions it must be considered the importance to a regular education of the child as well as to his ethnical, religious, cultural and linguistic origin"1 .

Application under the 1996 Hague Convention on parental responsibility and protection of children ${ }^{2}$ specifically includes in its area "the placement of the child in a foster family or institution, that is its custody with afala $^{3}$ or with with a similar custody"4 (art. 3, paragraph. e) assimilating kafala to the "western" child measures of protection concerning parental responsibility.

On the contrary, kafala was not considered in the 1993 Hague Convention on International adoptions stipulated among the Countries that took in consideration adoptions in order to better balance their positions. This Convention arose from a uniform legal environment, where not a hint had been made on the possible leveling between Islamic kafala and western adoption.

\section{The Idea of Kafala in the Italian Legal System}

In Italy, from the perusing of the previous jurisprudence, we can observe a strong preclusion from Italian diplomatic authorities to recognize kafala as adequate to legitimate the instance of families' reunification ${ }^{5}$ : the denial of visas was always explained on the basis of a literal and strict interpretation of the art. 29 of the law n. $286 / 1998^{6}$, according to the art. 4 EU directive 2003/86/EC of 22 September 2003 on the right to family reunification.

This art. 29 of the Italian immigration law provides that the foreigner who lives in Italy can ask for a reunification ${ }^{7}$ with their children who live abroad,

\footnotetext{
${ }^{1}$ UN Convention on the Rights of the Child, New York, 1989, art. 20, paragraph 3.

${ }^{2}$ The 1996 Hague Convention on Jurisdiction, Applicable Law, Recognition, Enforcement and Cooperation in respect of Parental Responsibility and Measures for the Protection of Children.

${ }^{3}$ The decision of putting kafala in the application area of 1996 Hagues' Convention was taken by Morocco.

${ }^{4}$ The 1996 Hague Convention on Jurisdiction, art. 3, paragraph. $e$.

${ }^{5}$ The different perspective according to which the legitimacy jurisprudence and the Italian consular authorities interpret this institute, of Islamic family jurisprudence, was at the base of a legal argument between the public administration and the magistrate.

${ }^{6}$ Better known as Italian immigration law

${ }^{7}$ The right of family unification is the expression of the person's right to maintain the familial unity as ratified by different international laws that amount to the safeguard of familiar life as an aspect of respect of men's rights. Among these we remember: the Universal Declaration of Man's rights (artt. 12 and 16), the European Convention of Man's rights (art. 8), The civil and political right Pact Right (art. 23); the Pact on economical, social and cultural rights (art. 10).
} 
specifying, at paragraph 2, that "adopted children, or given in custody, or in chancery are considered as sons" .

The first difficulty that arises is whether an analogical or extensive interpretation of this disposition is possible.

The Corte di Cassazione wanted to solve this doubt (sentence n. 7472 of 20.3.2008), highlighting that this art. 29 must be interpreted in the light of the Italian Constitution ${ }^{2}$. In particular, when the referential constitutional values are numerous and antagonist, only the interpretation of ordinary rules that balances these interests can be considered adequate.

Analysing the case of kafala, some contrasting values appear clearly: on one hand, protection of the child and of family unity, on the other hand the reduction of migration flows and the defence of the Country Territory.

The counterbalance made by the Corte Costituzionale (in legitimacy control's sphere) $)^{3}$ is fulfilled by the signal of a prevalence of the first value (child protection) over the second one (defence of territory and immigration control).

Considering that kafala is an foreigner institution, it is understandable how these particular cases may present "external elements", that don't need a perfect overlapping of institutions expected from the Italian legal system with those one expected from foreign systems, they rather need to be equitable considering the same goal they both want to reach in regards to protection.

It follows an extensive interpretation of the art. 29 of T.U. immigration, according to which the family reunification must also be allowed in the event of foreign protection instruments that, independently from their nomen iuris, produce similar effects to the ones provided for by Italian law institutions.

In support of this thesis it is necessary to make a reference to paragraph 3 of art. 28 of Italian immigration law, according to which it is claimed "all the administrative and juridical procedures that aim at affecting the right to family unity and the right of children, it must be considered with priority the best interest of the child, according to the art. 3, paragraph 1, of UN Convention on the rights of the Child, ratified in Italy with the law 27 May 1991, n. 176".

The reference to UN Convention on children's right "it's a univocal indicator of the legislator's will in recognizing kafala as one of the measures of protection of children which - in alternative to the combination adoption/custody - are appropriate to build the prerequisite for the family reunification of the non -European child.

Otherwise, as the Corte di Cassazione has discussed, it would come to the unacceptable consequence that a child whose custody was permitted in his Country could never reach his foster house built up in Italy. This would cause

\footnotetext{
${ }^{1}$ Art. 29 para.1 claims: "1. The foreigner can ask for the familial reunification for these relatives: a) spouse illegally separated; b) dependent children; even from the spouse or born out of the marriage, not married, that is legally separated, on the condition that the other parent, if exists, has given his approval; c) dependent parents.

${ }^{2}$ Cass. Civ, n. 7472 I section 20.3.2008, confirms App. Bologna 6.3.2007.

${ }^{3}$ Cfr. Cort. Cost., n. 198 e 205 del 2003.

${ }^{4}$ GELLI, R. (2008). La kafalah tra esigenze di tutela del minore e rischi di aggiramento della disciplina dell'immigrazione, Famiglia e Diritto, n. 7, 677.
} 
"a precondition of exclusion that would penalize all the children, from Islamic Countries, illegitimate, orphans or in abandon condition" .

In Italy, considering the content of the normative element and the numerous jurisprudential congruent sentences, it can be accepted that the right on family reunification in the abstract is extended, for analogia legis, to the kafala Islamic institution and therefore more generally we can conclude that the Italian judges consider as makful's best interest, the right to rejoin to their own kafil regularly resident in Italy, in order to live in a safe familiar environment.

\section{The Idea of Kafala in the French Legal System}

Even in France, the first problem arising from kafala has been related to the family reunification right of a makful to his kafil, who legally live in the French territory.

The French judiciary had to solve, several times, this nitpicking issue since the "Code de l'entrée et du séjour des étrangers et du droit d'asile" of 2005, kafala is not considered adequate to legitimate the request for the family reunification.

At first, French judges have constantly denied the family reunification to children given in custody with kafala, recognizing only the existence of biological or adoptive filiation as a requirement for a reunification ${ }^{2}$.

The Conseil d'Etat has restated how in any hypothesis of family reunification regarding a child, whether the kafil is French or foreigner, it is necessary to refer to art. 8 of European Convention of Human Rights. As a matter of fact, this article that claims the respect for private and familiar life and for "l'intérêt de l'enfant" becomes a fundamental criterion of decision, even though it is at judge's discretion for family reunification ${ }^{3}$.

The analysis of several sentences on this issue shows how the judges decide depending on a proof of the existence of a real familiar and private life

\footnotetext{
${ }^{1}$ Cass. Civ., 4.11.2005, n. 21395, infra, sect. III.

${ }^{2}$ The only existent exception concerning the Algerian kafala that French judges were invited to recognize a clause signed the 22nd of December 1985, which changed the first bilateral agreement Franco-Algerian the 27th of December, 1968.

This privilege was only given to Algerian makful to the detriment of those ones from other Islamic Countries, depending on this clause, which expressively set forth the right for an Algerian citizen, regularly residing in France, to benefit from the familial reunification, for members of his own family included dependent children under age, even sub kafala. Although in the third clause of the 1968 Franco-Algerian agreement, signed the 11th July of 2001, a supplemental condition is added, aiming at protecting the best interest for the child. Indeed, a kafil with French citizenship cannot claim the right to familial reunification for the child taken in custody, because one can suppose that, in this case, the best interest of the child is to live in his Country of origin with his biological family. It is given importance to "l'intérêt de l'enfant" that becomes an essential criterion of decision, even though it is under judges' discretion.

${ }^{3}$ Mbala, F. (2004), Adoption internationale: lorsque le pays d'origine prohibe l'adoption, Recueil Dalloz, n. 7., 458
} 
between makful and kafil, which cannot undoubtedly be proven just from kafala's concession. In particular, if makful is orphan, or he has been abandoned and his unique connection is with his kafil, denying the concession of an entry visa would deprive the makful of the only familial life he could enjoy. On the contrary, if the administrative judge verifies the existence of a makful's biological family from the Country of origin, he will consider that the best interest for the child is to stay in his Country of origin with his own biological family.

There is not a clear reference to art. 3 of 1989 UN Convention on the right of children, given for granted that the best interest for the child is staying with his biological family in his Country of origin.

As a consequence there is a certain ambiguity on the regulation of kafala as a prerequisite to the family reunification, given that French judges consider it, in the event of the existence of the child's biological family, in the child's best interest to stay in his Country of origin. Moreover, assuming that kafala's institution provides for the child to keep in touch with his biological parents, it can be gathered that in most cases the jurisdiction for reunification with a makful who lives in France will be rejected.

French jurisprudence seems to be evolved in relation to this issue, however, while at first it excluded kafala in relation to the fact it could not be included among the categories of filiation considered from the French system, today it excludes it de facto, referring to art. 8 of CEDU which provides for the respect of family unity, actually meaning the right of makful to live in his Country of origin with his biological family and not the right of growing up in France with his kafil.

\section{The Idea of Kafala in the English Legal System}

Kafala Islamic institution has caused some difficulties also to the English immigration law.

In the English immigration law, like the Italian and French immigration law, the kafala Islamic institution not mentioned among the prerequisites for the achievement of family reunification, since this institution is unknown to it. This means that a kafil domiciled in the UK has no right to remove the child from his/her own Country and bring him into English territory.

The Immigration rules sanctions that, in English law, the acknowledgment of child adoptions occurring in a foreign Country depends on the fact whether this Country belongs to those ones considered "designated countries", included in the additional list to the 1976 Adoption Act, reconfirmed from the 2002 Adoption and Children Act.

However, it has been highlighted that kafala is not a kind of adoption, but part 8 of paragraph 309 (A) of 2002 Adoption and Children Act also regulates the de facto adoption, according to which, if there is the proof of the fact that the bond between makful and kafil actually exists, Islamic kafala could be included. 
The rule that regulates the de facto adoption requires two essential requisites in order to be considered in this manner, in other words, the adoptive parents must prove that during the period spent abroad have:

"(i) lived together for a minimum of 18 months, of which the 12 months immediately preceding the application for entry clearance must have been spent living together with the child;

(ii) assumed the role of the child's parents, since the beginning of the 18 month period, so that there has been a genuine transfer of parental responsibility".

In the presence of these two requisites, English judges would be able to verify the actual relationship between makful and kafil, fully guaranteeing the best interest of the child and excluding any risk of recognizing false adoptions, behind which could be concealed possible human trafficking.

For this reason, in a sentence of Asylum and Immigration Tribunal (AIT), it has been underlined how this rule that regulates the de facto adoption "is probably not intended to facilitate the entry of children by themselves: it is probably intended to ensure that, if a number of members of the family are to come to the United Kingdom together, a child who has been living as a child of the family with the parents for some time is not left behind".

Although kafala can be compared to de facto adoption, the kafil may still have difficulties related to the achievement of reunification with a child sub kafala, in particular when he wants to prove a "genuine transfer of parental responsibility" as required from the disposition ${ }^{1}$, since this would imply a break of relationship with the child's family of origin, which kafala, on the contrary, does not assume ${ }^{2}$.

The necessity of proving these two requirements is used by English judges to verify the effective relationship between makful and kafil, fully guaranteeing the child's best interest and excluding any risk of false adoptions.

\section{Conclusion}

In Italy, judges have considered children sub kafala, like ones adopted or in custody, considering it in the best interest of the child, in order to live in a suitable familiar environment, to allow the right of reunification with their kafil who regularly live in Italy.

In France, the national judges in case of the presence of the child's biological family consider as best interest for the child to stay in his Country of origin. Considering that, in general, the relationships with biological parents

\footnotetext{
${ }^{1}$ See MCKEE, R. (2005).Children, David Jackson and George Warr (eds) Immigration: Law and Practice, Sweet \& Maxwell, London. See also SHAH, P. (2009). Transnational Hindu law adoption: recognition and treatment in Britain, International Journal of Law in Contest, Vol. 5, n. $2,107-130$.

${ }^{2}$ Part of the English doctrine has highlighted the failure of these regulations, that they would not make clear a real intent to the opening of English law towards new foreign institutes, but rather, a confirmation of a restrictive immigration politic.
} 
are not interrupted; we can deduce that, in most cases, the application for reunification with a kafil who lives in France will be rejected.

In England, on the contrary, judges tried to find a balance between the two divergent ideas of a child's best interest sub kafala established in Italy and France, with the admission of two requisites that regulate the adoption de facto, in which kafala can be included.

The analysis briefly developed highlights two important issues:

1) The process of transformation of our societies pushes the European legal systems into constant confrontation with foreign legal institutions,

2) It shows how the concept of the best interest of the child is not univocal.

In relation to the Islamic kafala institution, the main interest that European judges have shown is directed to a guarantee of the foreign child's best interest.

It becomes a fundamental issue to understand how to interpret "higher interests" or a child's priority: for this reason it is necessary to highlight how this concept cannot be defined in abstract terms.

Indeed, it is possible only ex post to value what best interest really means, in the sphere in which will emerge the real child's needs.

The complexity of this concept is amplified by the child's condition as an immigrant: the notion of "foreign child" as a matter of fact refers primarily to the two enacting constituents of this identity. The legal treatment of immigrant minors is caught between two legislations of opposite significance: the one concerning children characterized by protection and sustainment principles, and the other one concerning foreigners characterized by control and defense principles.

Therefore, the judge called to determine the best interest of the immigrant child finds himself not only the difficult position to choose between the application of two bodies of rules of opposite significance, but also to confront oneself with the concept of custody that changes in relation to the child's culture.

\section{Bibliography}

Baarsma, N.A. (2011). The Europeanisation of International Family Law, The Hague, Asser Press,.

David, René, Brierley, John E. C., (1985). Major Legal Systems in the World Today: An Introduction to the Comparative Study of Law. London. Stevens

Long, J. (2005). Il ricongiungimento familiare del minore affidato con Kafala, Diritto di famiglia, 1835-1836

Mbala, F. (2004), Adoption internationale: lorsque le pays d'origine prohibe l'adoption, Recueil Dalloz, n. 7., 458

Shah, P. (2009). Transnational Hindu law adoption: recognition and treatment in Britain, International Journal of Law in Contest, Vol. 5, n. 2, 107-130. 